Notas 



\title{
A REALISTIC LIBERTARIANISM
}

\author{
HANS-HERMANN HOPPE*
}

Fecha de recepción: FALTA.

Fecha de aceptación: FALTA.

«Libertarianism is logically consistent with almost any attitude toward culture, society, religion, or moral principle. In strict logic, libertarian political doctrine can be severed from all other considerations; logically one can be -and indeed most libertarians in fact are: hedonists, libertines, immoralists, militant enemies of religion in general and Christianity in particularand still be consistent adherents of libertarian politics. In fact, in strict logic, one can be a consistent devotee of property rights politically and be a moocher, a scamster, and a petty crook and racketeer in practice, as all too many libertarians turn out to be. Strictly logically, one can do these things, but psychologically, sociologically, and in practice, it simply doesn't work that way.» [my emphasis, $\mathrm{HHH}$ ]

Murray Rothbard, «Big-Government Libertarians,» in: L. Rockwell, ed., The Irrepressible Rothbard, Auburn, Al: Ludwig von Mises Institute, 2000, p. 101

Let me begin with a few remarks on libertarianism as a pure deductive theory.

If there were no scarcity in the world, human conflicts would be impossible. Interpersonal conflicts are always and everywhere conflicts concerning scarce things. I want to do $X$ with a given thing and you want to do $Y$ with the same thing.

Because of such conflicts - and because we are able to communicate and argue with each other- we seek out norms of behavior with the purpose of avoiding these conflicts. The purpose of norms is conflict-avoidance. If we did not want to

* FALTA 
avoid conflicts, the search for norms of conduct would be senseless. We would simply fight and struggle.

Absent a perfect harmony of all interests, conflicts regarding scarce resources can only be avoided if all scarce resources are assigned as private, exclusive property to some specified individual. Only then can I act independently, with my own things, from you, with your own things, without you and me coming into conflict.

But who owns what scarce resource as his private property and who does not? First: Each person owns his physical body that only he and no one else controls directly (I can control your body only in-directly, by first directly controlling my body, and vice versa) and that only he directly controls also in particular when discussing and arguing the question at hand. Otherwise, if body-ownership were assigned to some indirect body-controller, conflict would become unavoidable as the direct body-controller cannot give up his direct control over his body as long as he is alive; and in particular, otherwise it would be impossible that any two persons, as the contenders in any property dispute, could ever argue and debate the question whose will is to prevail, since arguing and debating presupposes that both, the proponent and the opponent, have exclusive control over their respective bodies and so come to the correct judgment on their own, without a fight (in a conflict-free form of interaction).

And second, as for scarce resources that can be controlled only indirectly (that must be appropriated with our own naturegiven, i.e., un-appropriated, body): Exclusive control (property) is acquired by and assigned to that person, who appropriated the resource in question first or who acquired it through voluntary (conflict-free) exchange from its previous owner. For only the first appropriator of a resource (and all later owners connected to him through a chain of voluntary exchanges) can possibly acquire and gain control over it without conflict, i.e., peacefully. Otherwise, if exclusive control is assigned instead to latecomers, conflict is not avoided but contrary to the very purpose of norms made unavoidable and permanent.

Let me emphasize that I consider this theory as essentially irrefutable, as a priori true. In my estimation this theory represents 
one of the greatest - if not the greatest - achievement of social thought. It formulates and codifies the immutable ground rules for all people, everywhere, who wish to live together in peace.

And yet: This theory does not tell us very much about real life. To be sure, it tells us that all actual societies, insofar as they are characterized by peaceful relations, adhere, whether consciously or subconsciously, to these rules and are thus guided by rational insight. But it does not tell us to what extent this is the case. Nor does it tell us, even if adherence to these rules were complete, how people actually live together. It does not tell us how close or distant from each other they live, if, when, how frequent and long, and for what purposes they meet and interact, etc.. To use an analogy here: Knowing libertarian theory - the rules of peaceful interactions - is like knowing the rules of logic - the rules of correct thinking and reasoning. However, just like the knowledge of logic, as indispensible as it is for correct thinking, does not tell us anything about actual human thought, about actual words, concepts, arguments, inferences and conclusions used and made, so the logic of peaceful interaction (libertarianism) does not tell us anything about actual human life and action. Hence: just as every logician who wants to make good use of his knowledge must turn his attention to real thought and reasoning, so a libertarian theorist must turn his attention to the actions of real people. Instead of being a mere theorist, he must also become a sociologist and psychologist and take account of «empirical» social reality, i.e., the world as it really is.

This brings me to the topic of «Left» and «Right.»

The difference between the Right and the Left, as Paul Gottfried has often noted, is a fundamental disagreement concerning an empirical question. The Right recognizes, as a matter of fact, the existence of individual human differences and diversities and accepts them as natural, whereas the Left denies the existence of such differences and diversities or tries to explain them away and in any case regards them as something unnatural that must be rectified to establish a natural state of human equality.

The Right recognizes the existence of individual human differences not just with regard to the physical location and make-up of the human environment and of the individual human 
body (its height, strength, weight, age, gender, skin- hair- or eye-color, facial features, etc., etc.). More importantly, the Right also recognizes the existence of differences in the mental makeup of people, i.e., in their cognitive abilities, talents, psychological dispositions, and motivations. It recognizes the existence of bright and dull, smart and dumb, short- and far-sighted, busy and lazy, aggressive and peaceful, docile and inventive, impulsive and patient, scrupulous and careless people, etc., etc.. The Right recognizes that these mental differences, resulting from the interaction of the physical environment and the physical human body, are the results of both environmental and physiological and biological factors. The Right further recognizes that people are tied together (or separated) both physically in geographical space and emotionally by blood (biological commonalities and relationships), by language and religion, as well as by customs and traditions. Moreover, the Right not merely recognizes the existence of these differences and diversities. It realizes also that the outcome of input-differences will again be different and result in people with much or little property, in rich and poor, and in people of high or low social status, rank, influence or authority. And it accepts these different outcomes of different inputs as normal and natural.

The Left on the other hand is convinced of the fundamental equality of man, that all men are «created equal.» It does not deny the patently obvious, of course: that there are environmental and physiological differences, i.e., that some people live in the mountains and others on the seaside, or that some men are tall and others short, some white and others black, some male and others female, etc.. But the Left does deny the existence of mental differences or, insofar as these are too apparent to be entirely denied, it tries to explain them away as «accidental.» That is, the Left either explains such differences as solely environmentally determined, such that a change in environmental circumstances (moving a person from the mountains to the seaside and vice versa, for instance, or giving each person identical pre- and postnatal attention) would produce an equal outcome, and it denies that these differences are caused (also) by some - comparatively intractable- biological factors. Or else, in those cases where it 
cannot be denied that biological factors play a causal role in determining success or failure in life (money and fame), such as when a 5 foot tall man cannot win an Olympic gold medal in the 100 meter dash or a fat and ugly girl cannot become Miss Universe, the Left considers these differences as pure luck and the resulting outcome of individual success or failure as undeserved. In any case, whether caused by advantageous or disadvantageous environmental circumstances or biological attributes, all observable individual human differences are to be equalized. And where this cannot be done literally, as we cannot move mountains and seas or make a tall man short or a black man white, the Left insists that the undeservedly «lucky» must compensate the «unlucky» so that every person will be accorded an «equal station in life,» in correspondence with the natural equality of all men.

With this short characterization of the Right and the Left I return to the subject of libertarianism. Is libertarian theory compatible with the world-view of the Right? And: Is libertarianism compatible with leftist views?

As for the Right, the answer is an emphatic «yes.» Every libertarian only vaguely familiar with social reality will have no difficulty acknowledging the fundamental truth of the Rightist worldview. He can, and in light of the empirical evidence indeed must agree with the Right's empirical claim regarding the fundamental not only physical but also mental in-equality of man; and he can in particular also agree with the Right's normative claim of «laissez faire,» i.e., that this natural human inequality will inevitably result also in un-equal outcomes and that nothing can or should be done about this.

There is only one important caveat, however. While the Right may accept all human inequalities, whether of starting-points or of outcomes, as natural, the libertarian would insist that only those inequalities are natural and should not be interfered with that have come into existence by following the ground-rules of peaceful human interaction mentioned at the beginning. Inequalities that are the result of violations of these rules, however, do require corrective action and should be eliminated. And moreover, the libertarian would insist that, as a matter of empirical fact, there exist quite a few among the innumerable observable human 
inequalities that are the result of such rule-violations, such as rich men who owe their fortune not to hard work, foresight, entrepreneurial talent or else a voluntary gift or inheritance, but to robbery, fraud or state-granted monopolistic privilege. The corrective action required in such cases, however, is not motivated by egalitarianism but by a desire for restitution: he (and only he), who can show that he has been robbed, defrauded or legally disadvantaged should be made whole again by those (and only those) who have committed these crimes against him and his property, including also cases where restitution would result in an even greater inequality (as when a poor man had defrauded and owed restitution to a rich one).

On the other hand: As for the Left, the answer is an equally emphatic «no.» The empirical claim of the Left, that there exist no significant mental differences between individuals and, by implication, between various groups of people, and that what appear to be such differences are due solely to environmental factors and would disappear if only the environment were equalized is contradicted by all everyday-life experience and mountains of empirical social research. Men are not and cannot be made equal, and whatever one tries in this regard, inequalities will always reemerge. However, it is in particular the implied normative claim and activist agenda of the Left that makes it incompatible with libertarianism. The leftist goal of equalizing everyone or equalizing everyone's «station in life» is incompatible with private property, whether in one's body or in external things. Instead of peaceful cooperation, it brings about unending conflict and leads to the decidedly un-egalitarian establishment of a permanent rulingclass lording it over the rest of the people as their «material» to be equalized. "Since," as Murray Rothbard has formulated it, «no two people are uniform or "equal" in any sense in nature, or in the outcomes of a voluntary society, to bring about and maintain such equality necessarily requires the permanent imposition of a power elite armed with devastating coercive power.»1

There exist countless individual human differences; and there exist even more differences between different groups of indi-

${ }^{1}$ Egalitarianism and the Elites, Review of Austrian Economics, 8, 2, 1995, p. 45. 
viduals, since each individual can be fit into countless different groups. It is the power-elite that determines which of these differences, whether of individuals or of groups, is to count as advantageous and lucky or disadvantageous and unlucky (or else as irrelevant). It is the power elite that determines how - out of countless possible ways - to actually do the «equalizing» of the lucky and the unlucky, i.e., what and how much to «take» from the lucky and «give» to the unlucky to achieve equality. In particular, it is the power elite, by defining itself as unlucky, that determines what and how much to take from the lucky and keep for itself. And whatever equalization is then achieved: Since countless new differences and inequalities are constantly reemerging, the equalizing-job of the power elite can never ever come to a natural end but must instead go on forever, endlessly.

The egalitarian world-view of the Left is not only incompatible with libertarianism, however. It is so out of touch with reality that one must be wondering how anyone can take it seriously. The man-on-the-street certainly does not believe in the equality of all men. Plain common sense and sound prejudice stand in the way of that. And I am even more confident that no one of the actual proponents of the egalitarian doctrine really, deep down, believes what he proclaims. Yet how, then, could the Leftist world-view have become the dominant ideology of our age?

At least for a libertarian, the answer should be obvious: the egalitarian doctrine achieved this status not because it is true, but because it provides the perfect intellectual cover for the drive toward totalitarian social control by a ruling elite. The ruling elite therefore enlisted the help of the «intelligentsia» (or the "chattering class»). It was put on the payroll or otherwise subsidized and in return it delivered the desired egalitarian message (which it knows to be wrong yet which is enormously beneficial to its own employment prospects). And so the most enthusiastic proponents of the egalitarian nonsense can be found among the intellectual class. ${ }^{2}$

${ }^{2}$ Murray Rothbard has listed them: «academics, opinion-molders, journalists, writers, media elites, social workers, bureaucrats, counselors, psychologists, personnel consultants, and especially for the ever accelerating new group-egalitarianism, a 
Given, then, that libertarianism and the egalitarianism professed by the Left are obviously incompatible, it must come as a surprise - and it is testimony to the immense ideological powers of the ruling elites and their court intellectuals- that many who call themselves libertarian today are, and consider themselves to be, part of the Left. How is such a thing possible?

What ideologically unifies these left-libertarians is their active promotion of various "anti-discrimination» policies and their advocacy of a policy of «free and non-discriminatory» immigration. $^{3}$

These «libertarians,» noted Rothbard, «are fervently committed to the notion that, while each individual might not be "equal" to every other, that every conceivable group, ethnic contingent, race, gender, or, in some cases, species, are in fact and must be made "equal," that each one has "rights" that must not be subject to curtailment by any form of "discrimination." $\rangle^{4}$

But how is it possible to reconcile this anti-discrimination stand with private property, which all libertarians are supposed to regard as the cornerstone of their philosophy, and which, after all, means exclusive property and hence, logically implies discrimination?

Traditional leftists, of course, do not have this problem. They do not think or care about private property. Since everyone is equal to everyone else, the world and everything on and in it belongs to everyone equally - all property is "common" property - and as an equal co-owner of the world everyone has of course an equal «right to access» to everywhere and everything.

veritable army of "therapists" and sensitivity trainers. Plus, of course, ideologues and researchers to dream up and discover new groups that need egalitarianizing.» (Ibid, p. 51)]

3 As for who among today's so-called libertarians is to be counted as a leftist, there is a litmus test: the position taken during the recent presidential primaries on Dr. Ron Paul, who is easily the purest of libertarians to ever gain national and even international attention and recognition. Beltway libertarians around Cato, George Mason, Reason, and various other outfits of the «Kochtopus» dismissed Ron Paul or even attacked him for his «racism» and lack of social «sensibility» and «tolerance,» i.e., in short: for being an upstanding «right-wing bourgeois,» leading an exemplary personal and professional life.

4 Ibídem, p. 102. 
Absent a perfect harmony of all interests, however, you cannot have everyone have equal property and equal access to everything and everywhere without leading to permanent conflict. Thus, to avoid this predicament, it is necessary to institute a State, i.e., a territorial monopolist of ultimate decision-making. «Common property,» that is, requires a State and is to become «State property.» It is the State that ultimately determines not just who owns what; and it is also the State, then, that ultimately determines the spatial allocation of all people: who is to live where and allowed to meet and have access to whom - and private property be damned. After all, it is they, the Lefties, who would control the State.

But this escape route is not open to anyone calling himself a libertarian. He must take private property seriously.

Psychologically or sociologically, the attraction of non-discrimination policies to libertarians can be explained by the fact that an over-proportionally large number of libertarians are misfits or simply odd —or to use Rothbard's description, «hedonists, libertines, immoralists, militant enemies of religion ...., moochers, scamsters, and petty crooks and racketeers»- who became attracted to libertarianism because of its alleged «tolerance» toward misfits and outliers, and who now want to use it as a vehicle to free themselves from all discrimination typically, in everyday life, dished out to their likes. But how do they do it «logically?» Left-libertarians, bleeding heart libertarians and humanitarian-cosmopolitan libertarians are not simply leftists. They know of the central importance of private property. Yet how can they seemingly logically reconcile the notion of private property with their promotion of anti-discrimination policies and in particular their propagation of a policy of discriminationfree immigration?

The short answer is: in placing all current private property and its distribution among distinct people under moral suspicion. With this claim, the left-libertarians fall into the opposite error from that committed by the non-libertarian Right. As indicated, the non-libertarian Right commits the error of regarding all (or at least almost all) current property holdings, including in particular also the property holdings of the State, as natural and 
just. In distinct opposition, a libertarian would recognize and insist that some present property holdings, and all (or at least most) State-holdings, are demonstrably unnatural and unjust and as such require restitution or compensation. In reverse, the left-libertarians claim that not only all or most State-holdings are unnatural und unjust (from this admission they derive their title «libertarian»), but that also all or most private property holdings are unnatural and unjust. And in support for this latter claim, they point to the fact that all current private property holdings and their distribution among various people have been affected, altered and distorted by prior State action and legislation and that everything would be different and no one would be in the same place and position he currently is had it not been for such prior State-interferences.

Without any doubt, this observation is correct. The State in its long history has made some people richer and others poorer than they would have been otherwise. It killed some people and let others survive. It moved people around from one place to another. It promoted some professions, industries or regions and prevented or delayed and changed the development of others. It awarded some people with privileges and monopolies and legally discriminated against and disadvantaged others, and on and on. The list of past injustices, of winners and losers, perpetrators and victims, is endless.

But from this indisputable fact it does not follow that all or most current property holdings are morally suspect and in need of rectification. To be sure, State-property must be restituted, because it has been unjustly acquired. It should be returned to its natural owners, i.e., the people (or their heirs) who were coerced to «fund» such "public» property by surrendering parts of their own private property to the State. However, I will not concern myself with this particular "privatization» issue here. ${ }^{5}$ Rather, it is the further-reaching claim that past injustices also render all current private property holdings morally suspect,

5 See on this subject Hans-Hermann Hoppe, «Of Private, Common and Public Property and the Rationale for Total Privatization,» Libertarian Papers, vol. 3., n.. 1 , 2011. http://libertarianpapers.org/articles/2011/lp-3-1.pdf 
which does not follow and which is certainly not true. As a matter of fact, most private holdings are likely just, irrespective of their history - unless and except in such cases in which a specific claimant can prove that they are not. The burden of proof, however, is on whoever challenges the current property holdings and distribution. He must show that he is in possession of an older title to the property in question than its current owner. Otherwise, if a claimant cannot prove this, everything is to remain as it currently is.

Or: To be more specific and realistic: From the fact that Peter or Paul or their parents, as members of any conceivable group of people, had been murdered, displaced, robbed, assaulted, or legally discriminated against in the past and their current property holdings and social positions would have been different if it had not been for such past injustices, it does not follow that any present member of this group has a just claim (for compensation) against the current property of anyone else (neither from within nor from outside his group). Rather, in each case, Peter or Paul would have to show, in one case after another, that he personally has a better because older title to some specified piece of property than some current, named and identified owner and alleged perpetrator. Certainly, a considerable number of cases exists where this can be done and restitution or compensation is owed. But just as certainly, with this burden of proof on any challenger of any current property distribution, not much mileage can be gained for any non-discriminatory-egalitarian agenda. To the contrary, in the contemporary Western world, replete with «affirmative action» laws that award legal privileges to various "protected groups» at the expense of various other correspondingly un-protected and discriminated groups, more - not less-discrimination and inequalities would result if, as justice would require, everyone who in fact could provide such individualized proof of his victimization was actually permitted to do so by the State and bring suit and seek redress from his victimizer.

But left-libertarians - the bleeding-heart and humanitariancosmopolitan libertarians- are not exactly known as «fighters» against «affirmative action.» Rather, and quite to the contrary, in order to reach the conclusion that they want to reach, they relax 
or dispense altogether with the requirement for someone claiming victimhood of offering individualized proof of victimization. Typically, in order to maintain their intellectual status as libertarians, the left-libertarians do so quietly, surreptitiously or even unknowingly, but in effect, in giving up this fundamental requirement of justice, they replace private property and property rights and rights violations with the muddled notion of "civil rights» and "civil rights violations» and individual rights with "group rights» and thus become closet-socialists. Given that the State has disturbed and distorted all private property holdings and distributions, yet without the requirement of individualized proof of victimization, everyone and every imaginable group can easily and without too much intellectual effort claim somehow «victimhood» vis-à-vis anyone else or any other group. ${ }^{6}$

Relieved of the burden of individualized proof of victimhood, the left-libertarians are essentially unrestricted in their «discovery» of new "victims» and «victimizers» in accordance with their own presupposed egalitarian assumptions. To their credit, they recognize the State as an institutional victimizer and invader of private property rights (again, from this derives their claim to be «libertarians»). But they see far more institutional and structural injustices and social distortions, far more victims and victimizers, and far more need for restitution, compensation and attendant property redistribution in the current world than only those injustices and distortions committed and caused by the State and to be resolved and rectified by shrinking and ultimately dismantling and privatizing all State holdings and functions.

${ }^{6}$ Characteristically, this stealthy transformation of libertarianism into closetsocialism via the confused notion of «civil rights,» has been identified decades ago already by Murray Rothbard. To quote him: «Throughout the Official Libertarian Movement [of left-libertarians], "civil rights" has been embraced without question, completely overriding the genuine rights of private property. In some cases, the embrace of a "right not to be discriminated against" has been explicit. In others, when libertarians want to square their new-found with their older principles, and have no aversion to sophistry and even absurdity, they take the sneakier path blazed by the American Civil Liberties Union: that if there should be so much as a smidgen of government involved, whether it be use of the public streets or a bit of taxpayer funding, then the so-called "right" of "equal access" must override either private property or indeed any sort of good sense.» Ibid, pp. 102/03. 
Even if the State were dismantled, they hold, as late and lasting effects of its long prior existence or of certain pre-State conditions, other institutional distortions would remain in place that required rectification to create a just society.

The views held by left-libertarians in this regard are not entirely uniform, but they typically differ little from those promoted by cultural Marxists. They assume as «natural,» without much if any empirical support and indeed against overwhelming evidence to the contrary, a largely «flat» and «horizonta» society of «equals,» i.e., of essentially universally and world-wide homogeneous, like-minded and -talented people of more or less similar social and economic status and standing, and they regard all systematic deviations from this model as the result of discrimination and grounds for some form of compensation and restitution. Accordingly, the hierarchical structure of traditional families, of sex roles and of the partition of labor between males and females, is considered unnatural. Indeed, all social hierarchies and vertical rank orders of authority, of headsmen and clanchiefs, of patrons, nobles, aristocrats and kings, of bishops and cardinals, of «bosses» generally, and of their respective underlings or subordinates, are viewed with suspicion. Similarly, all great or «excessive» disparities of income and wealth - of socalled «economic power»- and the existence of both a downtrodden under-class as well as of an upper class of super-wealthy people and families are deemed unnatural. As well, large industrial and financial corporations and conglomerates are considered artificial creatures of the State. And also suspect, unnatural and in need of repair are all exclusive associations, societies, congregations, churches and clubs, and all territorial segregation, separation and secession, whether based on class, gender, race, ethnicity, lineage, language, religion, profession, interests, customs or tradition.

From that vantage point, the «victim» groups and their «victimizers» are easily identified. As it turns out, «victims» make up the vast majority of mankind. Everyone and every conceivable group is a "victim,» except that small part of mankind composed of white (including northern Asian) heterosexual males, living traditional, bourgeois family lives. They, and especially the most 
creative and successful ones among them, (excluding interestingly only rich sports or entertainment celebrities) are the «victimizers» of everyone else.

While this view of human history strikes one as bizarre in light of the amazing civilizational achievements originating from precisely this minority group of "victimizers," it coincides almost completely with the victimology also propagated by cultural Marxists. Both groups only differ on the cause of this similarly identified, described and deplored «structural state of victimization.» For the cultural Marxists, the cause for this state of affairs is private property and unbridled capitalism based on private property rights. For them, the answer how to repair the damage done is clear and easy. All necessary restitution, compensation and redistribution are to be done by the State, which they presumably control.

For the left-libertarians this answer does not work. They are supposed to be in favor of private property and the privatization of State-property. They cannot have the State do the restitution, because as libertarians they are supposed to dismantle and ultimately abolish the State. Yet they want more restitution than only that resulting from the privatization of all so-called public property. Abolishing the State is not enough for them to create a just society. More is needed to compensate the just mentioned huge majority of victims.

But what? And on what grounds? Whenever there is individualized proof of victimization, i.e., if some person $A$ can demonstrate that another person B had invaded or taken A's property, or vice versa, no problem exists! The case is clear. But absent any such proof, what else is it that the "victimizers» owe their «victims,» and on what grounds? How to determine who owes whom how much and of what? And how to implement this restitution scheme in the absence of a State, and without thereby trampling on someone else's private property rights? This poses the central intellectual problem for any self-styled leftlibertarian.

Not surprisingly, the answer given by them to this challenge turns out evasive and vague. From all I can gather, it amounts to little more than an exhortation. As a keen observer of the intellectual scene has summarized it: «Be nice!» More precisely: You, 
you small group of "victimizers," must always be especially «nice,» forgiving, and inclusive vis-a-vis all members of the vast majority of «victims,» i.e., the long and familiar list of everyone except white, heterosexual males! And as for enforcement: All «victimizers» not demonstrating proper respect to some victimclass member, i.e., victimizers who are «nasty,» unforgiving or exclusive or who say "nasty» or disrespectful things about them, must be publicly shunned, humiliated, and shamed into obedience!

At first sight or hearing, this proposal how to do restitution may - as can be expected coming from "nice» people- appear, well, well meaning, harmless and plain «nice». In fact, however, it is anything but «nice» and harmless advice. It is wrong and dangerous.

First off: Why should anyone be particularly nice to anyone else -apart from respecting ones' respective private property rights in certain specified physical means (goods)? To be nice is a deliberate action and takes an effort, like all actions do. There are opportunity costs. The same effort could also be put to other effects. Indeed, many if not most of our activities are conducted alone and in silence, without any direct interaction with others, as when we prepare our meal, drive our car, or read and write. Time devoted to "niceness to others" is time lost to do other, possibly more worthwhile things. Moreover, niceness must be warranted. Why should I be nice to people who are nasty to me? Niceness must be deserved. Indiscriminating niceness diminishes and ultimately extinguishes the distinction between meritorious and faulty conduct. Too much niceness will be given to undeserving people and too little to deserving ones and the overall level of nastiness will consequently rise and public life become increasingly unpleasant.

Moreover, there are also genuinely evil people doing real evil things to real private property owners, most importantly the ruling elites in charge of the State-apparatus, as every libertarian would have to admit. One surely has no obligation to be nice to them! And yet, in rewarding the vast majority of «victims» with extra love, care and attention, one accomplishes precisely this: less time and effort is devoted to exhibiting nasty behavior 
toward those actually most deserving of it. The power of the State will not be weakened by universal «niceness,» then, but strengthened.

And why is it in particular the small minority of white, heterosexual males, and especially its most successful members that owes some extra-kindness to the vast majority of all other people? Why not the other way around? After all, most if not all technical inventions, machines, tools and gadgets in current use everywhere and anywhere, on which our current living standards and comforts largely and decisively depend, originated with them. All other people, by and large, only imitated what they had invented and constructed first. All others inherited the knowledge embodied in the inventors' products for free. And isn't it the typical white hierarchical family household of father, mother, their common children and prospective heirs, and their «bourgeois» conduct and lifestyle -i.e., everything the Left disparages and maligns - that is the economically most successful model of social organization the world has ever seen, with the greatest accumulation of capital goods (wealth) and the highest average standards of living? And isn't it only on account of the great economic achievements of this minority of «victimizers» that a steadily increasing number of «victims» could be integrated and partake in the advantages of a worldwide network of the division of labor? And isn't it only on account of the success of the traditional white, bourgeois family model also that so-called «alternative lifestyles» could at all emerge and be sustained over time? Do not most of today's «victims, , then, literally owe their lives and their current living to the achievements of their alleged «victimizers?»

Why not the «victims» giving special respect to their «victimizers»? Why not bestow special honor to economic achievement and success instead of failure, and why not give special praise to traditional, «normal» lifestyles and conduct rather than any abnormal alternative that requires, as a necessary condition of its own continued existence, a pre-existing dominant surrounding society of «normal» people with «normal» lifestyles?

I will come to the apparent answer to these rhetorical questions shortly. Before, however, a second - strategic - error in the left- 
libertarian advice of special niceness towards «historic victims» must be briefly addressed.

Interestingly, the «victim» groups identified by both left-libertarians and cultural Marxists differ little if at all from the groups identified as «underprivileged» and in need of compensation also by the State. While this poses no problem for cultural Marxists and can be interpreted as an indicator of the extent of control that they have already gained of the State apparatus, for left-libertarians this coincidence should be cause for intellectual concern. Why would the State pursue the same or similar end of «non-discrimination» of «victims» by "victimizers» that they, too, want to achieve, if only by different means? Left-libertarians are typically oblivious to this question. And yet to anyone with only some common sense the answer should be apparent.

In order to reach total control over each individual person, the State must pursue a divide et impera policy. It must weaken, undermine and ultimately destroy all other, rival centers of social authority. Most importantly, it must weaken the traditional, patriarchic family household, and especially the independently wealthy family household, as autonomous decision-making centers by sowing and legislating conflicts between wives and husbands, children and parents, women and men, rich and poor. As well, all hierarchical orders and ranks of social authority, all exclusive associations, and all personal loyalties and attachments -be it to a particular family, community, ethnicity, tribe, nation, race, language, religion, custom or tradition- except the attachment to a given State qua citizen-subject and passport holder, must be weakened and ultimately destroyed.

And what better way to do this than to pass anti-discrimination laws!

In effect, by outlawing all discrimination based on gender, sexual orientation, age, race, religion, national origin, etc., etc., a vast number of people are declared State-certified «victims.» Anti-discrimination laws, then, are an official call upon all «victims» to find fault and complain to the State about their own «favorite» "oppressors," and especially the more wealthy ones among them, and their "oppressive» machinations, i.e., their «sexism,» «homophobia,» «chauvinism,» «nativism,» «racism,» 
«xenophobia,» or whatever, and for the State to respond to such complaints by cutting the "oppressors» down to size, i.e., in successively dispossessing them of their property and authority and correspondingly expanding and strengthening its own monopolistic power vis-a-vis an increasingly weakened, fragmented, fractionalized and de-homogenized society.

Ironically, then, and contrary to their self-proclaimed goal of wanting to shrink or even eliminate the State, the left-libertarians with their peculiar, egalitarian victimology become accomplices to the State and effectively contribute to the aggrandizement of its power. Indeed, the left-libertarian vision of a discriminationfree multicultural society is, to use Peter Brimelow's phrase, Viagra to the State.

Which brings me to my final subject.

The role of left-libertarianism as Viagra to the State becomes even more apparent when one considers their position on the increasingly virulent question of migration. Left-libertarians are typically ardent advocates in particular of a policy of «free and non-discriminatory» immigration. If they criticize the State's immigration policy, it is not for the fact that its entry restrictions are the wrong restrictions, i.e., that they do not serve to protect the property rights of domestic citizen, but for the fact that it imposes any restrictions on immigration at all.

But on what grounds should there be a right to un-restricted, «free» immigration? No one has a right to move to a place already occupied by someone else, unless he has been invited by the present occupant. And if all places are already occupied, all migration is migration by invitation only. A right to «free» immigration exists only for virgin country, for the open frontier.

There are only two ways of trying to get around this conclusion and still rescue the notion of «free» immigration. The first is to place all current place occupants and occupations under moral suspicion. To this purpose, much is made of the fact that all current place occupations have been affected by prior Stateaction, war and conquest. And true enough, State borders have been drawn and redrawn, people have been displaced, deported, killed and resettled, and state-funded infrastructure projects (roads, public transportation facilities, etc., etc.) have affected the 
value and relative price of almost all locations and altered the travel distance and cost between them. As already explained in a slightly different context, however, from this undisputable fact it does not follow that any present place occupant has a claim to migrate to any place else (except, of course, when he owns that place or has permission from its current owner). The world does not belong to everyone.

The second possible way out is to claim that all so-called public property - the property controlled by local, regional or central government - is akin to open frontier, with free and unrestricted access. Yet this is certainly erroneous. From the fact that government property is illegitimate because it is based on prior expropriations, it does not follow that it is un-owned and free-for-all. It has been funded through local, regional, national or federal tax payments, and it is the payers of these taxes, then, and no one else, who are the legitimate owners of all public property. They cannot exercise their right - that right has been arrogated by the State- but they are the legitimate owners.

In a world where all places are privately owned, the immigration problem vanishes. There exists no right to immigration. There only exists the right to trade, buy or rent various places. Yet what about immigration in the real world with public property administered by local, regional or central State-governments?

First off: What would immigration policies be like if the State would, as it is supposed to do, act as a trustee of the taxpayerowners' public property? What about immigration if the State acted like the manager of the community property jointly owned and funded by the members of a housing association or gated community?

At least in principle the answer is clear. A trustee's guideline regarding immigration would be the «full cost» principle. That is, the immigrant or his inviting resident should pay the full cost of the immigrant's use made of all public goods or facilities during his presence. The cost of the community property funded by resident taxpayers should not rise or its quality fall on account of the presence of immigrants. On the contrary, if possible the presence of an immigrant should yield the resident-owners a profit, either in the form of lower taxes or community-fees or a 
higher quality of community property (and hence all-around higher property values).

What the application of the full cost principle involves in detail depends on the historical circumstances, i.e., in particular on the immigration pressure. If the pressure is low, the initial entry on public roads may be entirely unrestricted to «foreigners» and all costs insofar associated with immigrants are fully absorbed by domestic residents in the expectation of domestic profits. All further-going discrimination would be left to the individual resident-owners. (This, incidentally, is pretty much the state of affairs, as it existed in the Western world until WW I.) But even then, the same generosity would most likely not be extended to the use made by immigrants of public hospitals, schools, universities, housing, pools, parks, etc.. Entry to such facilities would not be «free» for immigrants. To the contrary, immigrants would be charged a higher price for their use than the domestic resident-owners who have funded these facilities, so as to lower the domestic tax-burden. And if a temporary visitor-immigrant wanted to become a permanent resident, he might be expected to pay an admission price, to be remitted to the current owners as compensation for the extra-use made of their community property.

On the other hand, if the immigration pressure is high - as currently in the entire Western, white, heterosexual male dominated world- more restrictive measures may have to be employed for the same purpose of protecting domestic resident owners' private and common property. There may be identity controls not only at ports of entry, but also at the local level, in order to keep out known criminals and otherwise undesirable riffraff. And apart from the specific restrictions imposed on visitors by individual resident-owners regarding the use of their various private properties, there may also exist more general local entry restrictions. Some especially attractive communities may charge an entrance fee for every visitor (except for resident-invited guests) to be remitted to resident-owners, or require a certain code of conduct regarding all community property. And the requirements of permanent ownership-residency for some communities may be highly restrictive and involve inten- 
sive screening and a heavy admission price, as is still the case today in some Swiss communities.

But of course, then: this is not what the State does. The immigration policies of the States that are confronted with the highest immigration pressure, of the US and Western Europe, have little resemblance with the actions of a trustee. They do not follow the full cost principle. They do not tell the immigrant essentially to «pay up or leave.» To the contrary, they tell him «once in, you can stay and use not just all roads but all sorts of public facilities and services for free or at discounted prices even if you do not pay up.» That is, they subsidize immigrants - or rather: they force domestic taxpayers to subsidize them. In particular, they also subsidize domestic employers who import cheaper foreign workers. Because such employers can externalize part of the total costs associated with their employment - the free use to be made by his foreign employees of all resident public property and facilities - onto other domestic taxpayers. And they still further subsidize immigration (internal migration) at the expense of resident-taxpayers in prohibiting - by means of non-discrimination laws- not only all internal, local entry restrictions, but also and increasingly all restrictions concerning the entry and use of all domestic private property.

And as for the initial entry of immigrants, whether as visitor or resident, States do not discriminate on the basis of individual characteristics (as a trustee would, and as every private property owner would, regarding his own property), but on the basis of groups or classes of people, i.e., based on nationality, ethnicity, etc.. They do not apply a uniform admission standard: of checking the identity of the immigrant, of conducting some sort of credit check on him, and possibly charging him an entrance fee. Instead, they allow some classes of foreigners in for free, without any visa requirement, as if they were returning residents. Thus, for instance, all Rumanians or Bulgarians, irrespective of their individual characteristics, are free to migrate to Germany or the Netherlands and stay there to make use of all public goods and facilities, even if they do not pay up and live at German or Dutch taxpayers' expense. Similarly for Puerto Ricans vis-à-vis the US and US taxpayers, and also for Mexicans, who are effectively 
allowed to enter the US illegally, as uninvited and unidentified trespassers. On the other hand, other classes of foreigners are subject to painstaking visa restrictions. Thus, for instance, all Turks, again irrespective of their individual characteristics, must undergo an intimidating visa-procedure and may be entirely prevented from traveling to Germany or the Netherlands, even if they have been invited and command over sufficient funds to pay for all costs associated with their presence.

Resident owner-taxpayers are thus harmed twice: once by indiscriminatingly including some classes of immigrants even if they can't pay up and on the other hand by indiscriminatingly excluding other classes of immigrants even if they can.

Left-libertarians do not criticize this immigration policy as contrary to that of a trustee of public property ultimately owned by private domestic taxpayer-owners, however, i.e., for not applying the full-cost principle and hence wrongly discriminating, but for discriminating at all. Free, non-discriminatory immigration for them means that visa-free entry and permanent residency be made available to everyone, i.e., to each potential immigrant on equal terms, regardless of individual characteristics or the ability to pay for the full cost of one's stay. Everyone is invited to stay in Germany, the Netherlands, Switzerland or the US, for instance, and make free use of all domestic public facilities and services.

To their credit, left-libertarians recognize some of the consequences this policy would have in the present world. Absent any other, internal or local entry restrictions concerning the use of domestic public properties and services and increasingly absent also all entry restrictions regarding the use of domestic private property (owing to countless anti-discrimination laws), the predictable result would be a massive inflow of immigrants from the third and second world into the US and Western Europe and the quick collapse of the current domestic "public welfare» system. Taxes would have to be sharply increased (further shrinking the productive economy) and public property and services would dramatically deteriorate. A financial crisis of unparalleled magnitude would result.

Yet why would this be a desirable goal for anyone calling himself a libertarian? True enough, the tax-funded public welfare 
system should be eliminated, root and branch. But the inevitable crisis that a «free» immigration policy would bring about does not produce this result. To the contrary: Crises, as everyone vaguely familiar with history would know, are typically used and often purposefully fabricated by States in order to further increase their own power. And surely the crisis produced by a «free» immigration policy would be an extraordinary one.

What left-libertarians typically ignore in their nonchalant or even sympathetic appraisal of the predictable crisis is the fact that the immigrants who caused the collapse are still physically present when it occurs. For left-libertarians, owing to their egalitarian preconceptions, this fact does not imply a problem. For them, all people are more or less equal and hence, an increase in the number of immigrants has no more of an impact than an increase of the domestic population via a higher birthrate. For every social realist, however, indeed for everyone with any common sense, this premise is patently false and potentially dangerous. A million more Nigerians or Arabs living in Germany or a million more Mexicans or Hutus or Tutsis residing in the US is quite a different thing than a million more home-grown Germans or Americans. With millions of third- and second-world immigrants present when the crisis hits and the paychecks stop coming in, it is highly unlikely that a peaceful outcome will result and a natural, private-property-based social order emerge. Rather, it is far more likely and indeed almost certain that civil war, looting, vandalism, and tribal or ethnic gang warfare will break out instead -and the call for a strong-man-State will become increasingly unmistakable.

Why, then, one might ask, does the State not adopt the leftlibertarian «free» immigration policy and grasp the opportunity offered by the predictable crisis to further strengthen its own power? Through its internal non-discrimination policies and also its current immigration policies, the State has already done much to fragment the domestic population and so increase its own power. A «free immigration» policy would add another, enormous dose of non-discriminatory «multiculturalism.» It would further strengthen the tendency toward social de-homogenization, division and fragmentation, and it would further weaken the traditional, 
white, heterosexual male dominated «bourgeois» social order and culture associated with the «West.»

The answer as to "why not?» appears simple, however. In contrast to left-libertarians, the ruling elites are still realistic enough to recognize that besides great opportunities for State growth, the predictable crisis would also entail some incalculable risk and could lead to social upheavals of such proportions that they themselves may be swept out of power and be replaced by other, «foreign» elites. Accordingly, the ruling elites proceed only gradually, step by step, on their path toward a «nondiscriminatory multiculturalism.» And yet they are happy about the left-libertarian «free immigration» propaganda, because it helps the State not just to stay on its present divide et impera course but to proceed on it at an accelerated pace.

Contrary to their own anti-statist pronouncements and pretensions, then, the peculiar left-libertarian victimology and its demand for undiscriminating niceness and inclusiveness vis-avis the long, familiar list of historical «victims," including in particular also all foreigners qua potential immigrants, actually turns out to be a recipe for the further growth of State power. The cultural Marxists know this, and that is the reason why they adopted the very same victimology. The left-libertarians do apparently not know this and are thus the cultural Marxists' useful idiots on their march toward totalitarian social control.

Let me come to a conclusion and return to libertarianism, and the topic of Left and Right — and thereby finally also to the answer to my earlier rhetorical questions concerning the peculiar leftist victimology and its significance.

You cannot be a consistent left-libertarian, because the leftlibertarian doctrine, even if unintended, promotes Statist, i.e., unlibertarian, ends. From this, many libertarians have drawn the conclusion that libertarianism is neither Left nor Right. That it is just «thin» libertarianism. I do not accept this conclusion. Nor, apparently, did Murray Rothbard, when he ended the initially presented quote saying: «but psychologically, sociologically, and in practice, it simply doesn't work that way.» Indeed, I consider myself a right-libertarian —or, if that may sound more appealing, a realistic or commonsensical libertarian- and a consistent one at that. 
True enough, the libertarian doctrine is a purely aprioristic and deductive theory and as such does not say or imply anything about the rival claims of the Right and the Left regarding the existence, the extent and the causes of human inequalities. That is an empirical question. But on this question the Left happens to be largely unrealistic, wrong and devoid of any common sense, whereas the Right is realistic and essentially correct and sensible. There can be consequently nothing wrong with applying a correct aprioristic theory of how peaceful human cooperation is possible to a realistic, i.e., fundamentally rightist, description of the world. For only based on correct empirical assumptions about man is it possible to arrive at a correct assessment as regards the practical implementation and the sustainability of a libertarian social order.

Realistically, then, a right-libertarian does not only recognize that physical and mental abilities are unequally distributed among the various individuals within each society and that accordingly each society will be characterized by countless inequalities, by social stratification and a multitude of rank orders of achievement and authority. He also recognizes that such abilities are unequally distributed among the many different societies coexisting on the globe and that consequently also the world-as-a-whole will be characterized by regional and local inequalities, disparities, stratification and rank orders. As for individuals, so are also not all societies equal and on a par with each other. He notices further that among these unequally distributed abilities, both within any given society and between different societies, is also the mental ability of recognizing the requirements and the benefits of peaceful cooperation. And he notices that the conduct of the various regional or local States and their respective power elites that have emerged from different societies can serve as a good indicator for the various degrees of deviation from the recognition of libertarian principles in such societies.

More specifically, he realistically notices that libertarianism, as an intellectual system, was first developed and furthest elaborated in the Western world, by white males, in white male dominated societies. That it is in white, heterosexual male dominated societies, where adherence to libertarian principles is the greatest 
and the deviations from them the least severe (as indicated by comparatively less evil and extortionist State policies). That it is white heterosexual men, who have demonstrated the greatest ingenuity, industry, and economic prowess. And that it is societies dominated by white heterosexual males, and in particular by the most successful among them, which have produced and accumulated the greatest amount of capital goods and achieved the highest average living standards.

In light of this, as a right-libertarian, I would of course first say to my children and students: always respect and do not invade others' private property rights and recognize the State as an enemy and indeed the very anti-thesis of private property. But I would not leave it at that. I would not say (or silently imply) that once you have satisfied this requirement «anything goes.» Which is pretty much what «thin» libertarians appear to be saying! I would not be a cultural relativist as most «thin» libertarians at least implicitly are. Instead, I would add (at a minimum): be and do whatever makes you happy, but always keep in mind that as long as you are an integral part of the worldwide division of labor, your existence and well-being depends decisively on the continued existence of others, and especially on the continued existence of white heterosexual male dominated societies, their patriarchic family structures, and their bourgeois or aristocratic lifestyle and conduct. Hence, even if you do not want to have any part in that, recognize that you are nonetheless a beneficiary of this standard «Western» model of social organization and hence, for your own sake, do nothing to undermine it but instead be supportive of it as something to be respected and protected.

And to the long list of «victims» I would say: do your own thing, live your own life, as long as you do it peacefully and without invading other people's private property rights. If and insofar as you are integrated into the international division of labor, you do not owe restitution to anyone nor does anyone owe you any restitution. Your coexistence with your supposed «victimizers» is mutually beneficial. But keep in mind that while the "victimizers» could live and do without you, albeit at a lower standard of living, the reverse is not true. The disappearance of the «victimizers» would imperil your very own existence. Hence, 
even if you don't want to model yourself on the example provided by white male culture, be aware that it is only on account of the continued existence of this model that all alternative cultures can be sustained at their present living standards and that with the disappearance of this «Western» model as a globally effective Leitkultur the existence of many if not all of your fellow «victims» would be endangered.

That doesn't mean that you should be uncritical of the "Western,» white male dominated world. After all, even these societies most closely following this model also have their various States that are responsible for reprehensible acts of aggression not only against their own domestic property owners but also against foreigners. But neither where you live nor anywhere else should the State be confused with «the people.» It is not the «Western» State, but the «traditional» (normal, standard, etc.) lifestyle and conduct of the western "people,» already under increasingly heavy attack by their very "own» State-rulers on their drive toward totalitarian social control, that deserves your respect and of which you are a beneficiary. 
